\title{
Pengaruh Dosis Pupuk Bokashi Super Terhadap Pertumbuhan Bibit Buni (Antidesma buniusL. Spreng)
}

\author{
Novita Anggraini ${ }^{1}$ dan Nurliana ${ }^{1}$ \\ Email: novita.novi.anggraini@gmail.com
}

\begin{abstract}
ABSTRAK
Antidesma bunius L. Spreng atau sering dikenal dengantanaman buni merupakan tanaman multifungsi dari famili Euphorbiaceae.Buni bermanfaat baik secara ekologis dan ekonomis. Namun, eksistensi dan potensi tanaman Buni ini belum terungkap dibandingkan dengan kurangnya informasi dan teknik budidaya buni.Pemberiaan pupuk merupakan salah satu upaya peningkatkan pertumbuhan dalam budidaya Buni . Tujuan Penelitian ini adalah untuk mengetahui pengaruh dosis pupuk bokashi super terhadap pertumbuhan bibit buni (Antidesma bunius L. Spreng). Penelitian ini dilaksanakan dari Agustus s.d Oktober 2017. Rancangan yang digunakan dalam penelitian adalah Rancangan Acak Kelompok (RAK) Non Faktorial yang terdiri dari perlakuan dosis pupuk bokashi super A (Kontrol); B(100 g/polybag);C (200 g/polybag), D (300 g/polybag), dan E(400 g/Polybag).Setiap perlakuan diulang sebanyak 5 (lima) kali. Analisis data yang digunakan adalah analisis tren. Perlakuan pemberian beberapa dosis pupuk Bokashi pada tanaman Buni umur satu tahun tidak memberikan perbedaan pertumbuhan yang cukup nyata dengan perlakuan tanpa diberi pupuk. Pertumbuhan tanaman buni yang konsisten meningkat pada pertumbuhan diameter, tinggi maupun jumlah daun terdapat pada tanaman yang diberi perlakuan pupuk $200 \mathrm{~g} /$ polybag.
\end{abstract}

KATA KUNCI:Bibit Buni, Antidesma bunius, Pupuk Bokashi

Keywords:Buni Seedling, Antidesma bunius, Bokashi Super

Antidesma bunius L.Spreng which known as Bunplant is a species belongs to to family EuphorbiaceaeWhich has manybenefits both ecological and economically . However,the existence and potential of Buni plants have not been revealed compare due to the lack of information and the cultivation techniques of Buni..Fertilization is one of theways to increase growth of Buni plant. This study was conducted to determine the effect of Super Bokashi doses on the growth of Buni seedling. This study was conducted from August to Oktober 2017. The design method used in this study was a Non-factorial Randomized Block Design (RBD) consisting of treatment of super Bokashi A (Control) (0g/polybag); B (100 g / polybag); C (200 g / polybag), D (300 g / polybag), and E (400 g / Polybag).. Each treatment wasrepeated 5(five) times. The data analysis used was tren analysis. Super Bokashi application in any treatment on Buni seedling were not different significantly compared to control. treatment with The treatment with $200 \mathrm{~g}$ Bokashi/polybag possessed consisten growth of Buni seedling in hight, diameter and amount of leaves.

Keywords:Buni Seedling, Antidesma bunius, Bokashi Super

Pendahuluan

Pupuk bokashi merupakan salah satu alternatif dalam penerapan teknologi pertanian organik yang berwawasan lingkungan dan berkelanjutan. Bokashi mempunyai peluang yang baik untuk dijadikan pupuk organik karena

${ }^{1}$ Budidaya Pertanian, Fakultas Pertanian, Universitas Nahdlatul Ulama Sumatera Utara 
mempunyai kandungan unsur hara yang cukup tinggi (Hamzah,2007).Bokashi adalah pupuk organik hasil fermentasi bahan organik dengan menggunakan EM, dimana EM Q merupakan suatu campuran mikro organisme yang bermanfaat untuk meningkatkan keaneka-ragaman mikroba dari tanah dan tanaman, dan berfungsi untuk meningkatkan pertumbuhan dan produksi tanaman, serta meningkatkan kesehatan tanah (IP2TP, 2000).Kehadiran Effective Microorganism 4(EM4) memiliki peran aktif dalam meningkatkanproduksi, menekanpertumbuhan patogen tanaman, meningkatkan aktivitas mikroorganisme yang menguntungkan seperti mikoriza, rhizobium, bakteri pelarut posfat, serta mengurangi kebutuhan pupuk dan pestisida kimia (Higa \& Widana, 1996).

Buni (Antidesma bunius, L. Spreng) tumbuh liar di daerah-daerah basah. Di Indonesia tanaman ini terdapat di daerah kering di bagian timur Jawa ataupun di bagian barat Jawa yang beriklim lembab. Tumbuhan ini biasanya proses suksesi tahap awal sebuah hutan sekunder(Wulandari, 2011). Buni juga merupakan jenis pohon yang multi fungsi, baik secara ekologis maupun ekonomis. Buah buni dapatdimakan mentah atau dimasak, dijadikan jus, jelly atau selai (Lim 2012; Ong \& Kim, 2016). Buah buni juga mengandung antioksidan yang tinggi dan komposisi fenolik yang tinggi (Kassem, 2013).Daun mudanya juga dapat dimakan mentah dengan nasi atau digunakan sebagai perasa masakan (Lim, 2012). Kulit pohon Buni dapat dijadikan tali temali(Hazarika \&Singh 2017). Pohon Buni merupakan pohon yang menyerap karbon terbesar diantara pohon-pohon yang ditanam di Hutan Kota Medan (Gratimah, 2009).

Teknik budidaya buni belum banyak diteliti termasuk pemberian dosis pupuk pada bibit buni. Sehingga penelitian ini dilakukan untuk mengetahui pengaruh pemberian pupuk bokashi terhadap pertumbuhan bibit Buni umur 1 tahun.

\section{Metode Penelitian}

\section{Lokasi Penelitian}

Penelitian ini dilaksanakan di Kelurahan Tanjung Mulia, Kecamatan Medan Deli mulai Agustussampai denganOktober 2017.

\section{Bahan dan Alat}

Alat-alat yang digunakan adalah polybag ukuran $20 \times 50 \mathrm{~cm}$, penggaris, jangka sorong digital, meteran, gunting, timbangan, ember, patok kayu dan kertas label.Bahan-bahan yang digunakan adalah tanah, bibit buni (Antidesma bunius L. Spreng), dan pupuk bokashi super.

\section{Rancangan Penelitian}

Rancangan yang digunakan pada penelitian ini adalah Rancang Acak Kelompok (RAK) Non Faktorial, terdiri dari 5 (lima) perlakuan dan diulang 5 (lima) kali. Perlakuan terdiri dari :

A : Kontrol (tanpa pupuk Bokashi super)

B : $100 \mathrm{~g}$ pupuk bokashi super/polybag

C : $200 \mathrm{~g}$ pupuk bokashi super/polybag

D : $300 \mathrm{~g}$ pupuk bokashi super/polybag

E : 400 g pupuk bokashi super/polybag

Data diolah dengan menggunakan analisis tren. Parameter yang diamati yaitu tinggi tanaman,diameter batang dan jumlah daun.

\section{Prosedur penelitian}

\section{Persiapan Media Tanam}

Tanah dibersihkan dari bebatuan dan potongan kayu.Pupuk bokashi super ditimbang sesuai dengan perlakuan.Tanah sebanyak $8 \mathrm{~kg}$ dicampur dengan pupuk bokashi super sesuai dengan perlakuan. Kemudian diberi label.

\section{Penanaman}

Bibit Buni dikeluarkan dari Polybag dengan cara menyobek polybag dengan hati-hati untuk mengurangi kerusakan akar. Lubang tanam dibuat tepat 
di tengah-tengah polybag. Bibit Buni dipindahkan ke polybag sesuai dengan perlakuan, kemudian diberi label.

\section{Pemeliharaan}

Pemeliharaan dilakukan dengan menjaga kelembaban tanah dan penyiraman bibit Buni dilakukan jika diperlukan

\section{Pengamatan}

Pengamatan dilakukan terhadap tinggi tanaman, diameter batang, pertambahan daun dan luas daun. Untuk mengukur diameter batang digunakan jangka sorong, untuk tinggi tanaman digunakan penggaris atau meteran. Pengamatan dilakukan pada pagi hari setiap Minggu.

\section{Hasil Dan Pembahasan}

\section{Gambaran Umum Penelitian}

Analisis data yang digunakan pada penelitian ini adalah analisis tren. Analisis tren digunakan karena mewakili jumlah sampel yang diteliti.

Suhu rata-rata minimum pada saat penelitian adalah $20^{\circ} \mathrm{C}$ dan suhu rata-rata maksimum adalah $30{ }^{\circ} \mathrm{C}$ dengan kelembaban rata-rata $70-95 \%$ dan sifat hujan yang berkisar $116-150 \%$ perbulan (BMKG, 2017).

\section{Diameter Tanaman}

Berdasarkan analisis tren (Gambar 1) diketahui bahwa pertumbuhan diameter Buni terus meningkat setiap minggunya. Pertumbuhan diameter antar perlakuan tidak terlalu berbeda. Pertumbuhan diameter tertinggi pada minggu keenam terlihat pada tanaman dengan perlakuan pemberian pupuk $100 \mathrm{~g} /$ polybag dan tidak terlalu jauh berbeda dengan tanaman tanpa pemberian pupuk dan diikuti oleh tanaman yang diberi perlakuan pupuk $200 \mathrm{~g} /$ polybag. Pertumbuhan diameter yang paling pesat terjadi pada minggu ketiga menuju minggu keempat.

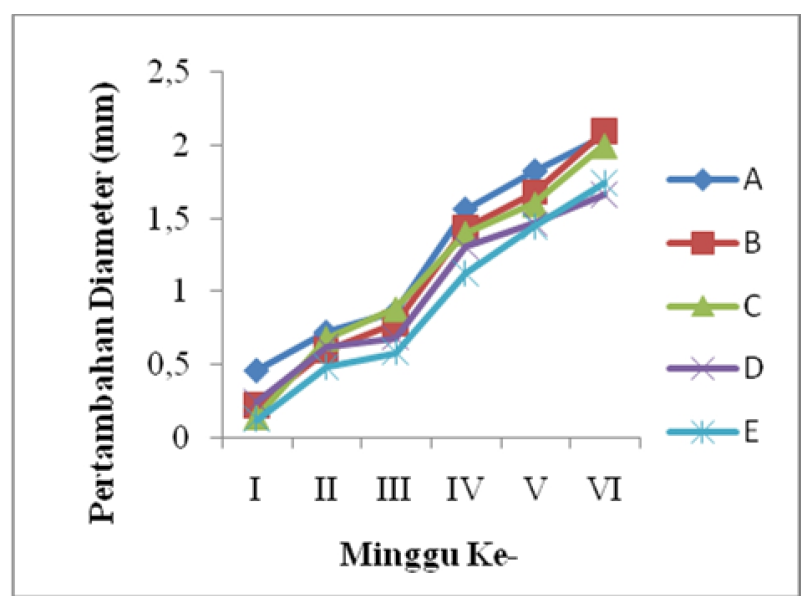

Gambar 1. Grafik Pertumbuhan Diameter, Tinggi dan Jumlah Daun; A (Kontrol/tanpa pupuk Bokashi super), B (100 g pupuk bokashi super/polybag), C (200 g pupuk bokashi super/polybag), D (300 g pupuk bokashi super/polybag), E (400 g pupuk bokashi super/polybag)

\section{Tinggi Tanaman}

Berdasarkan analisis tren (Gambar 1) diketahui bahwa pertumbuhan tinggi tanaman Buni mengalami peningkatan setiap minggunya.Pertumbuhan tinggi antar perlakuan tidak terlalu berbeda. Tanaman yang diberi pupuk $100 \mathrm{~g} /$ polybag terlihat paling mendominasi pertumbuhan tinggi tanaman, diikuti dengan tanaman yang diberi perlakuan pupuk 200 g/polybag. Peningkatan pertumbuhan tinggi tanaman yang cukup pesat terjadi mulai minggu ketiga.

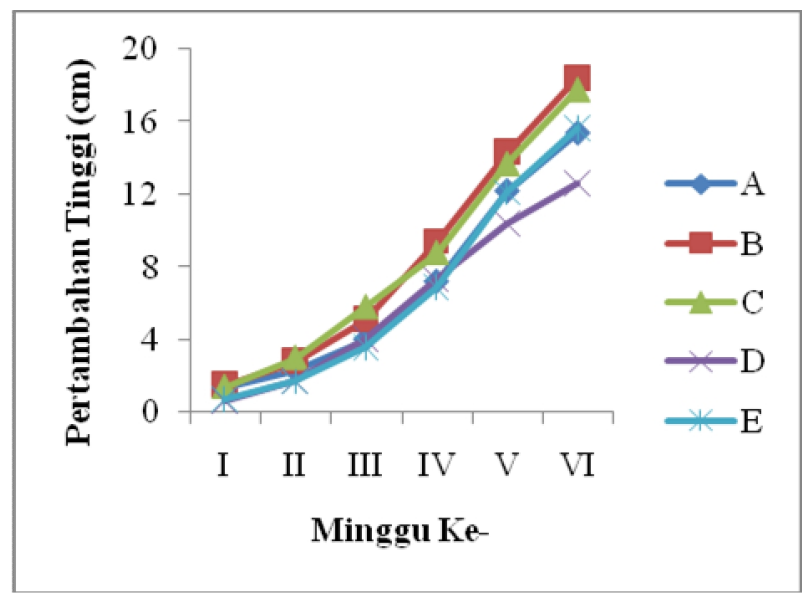

\section{Jumlah Daun}

Berdasarkan analisis tren (Gambar 1) terlihat bahwa jumlah daun semakin bertambah setiap minggunya. Dan 
pertambahan jumlah daun antar setiap perlakuan tidak terlalu berbeda dan cenderung serupa baik pada minggu terakhir pengamatan (keenam) maupun setiap minggu pengamatan. Jumlah daun tertinggi pada minggu keenam terdapat pada perlakuan pemberian pupuk 200 g/polybag dan diikuti dengan tanaman yang diberi pupuk $100 \mathrm{~g} /$ polybag.

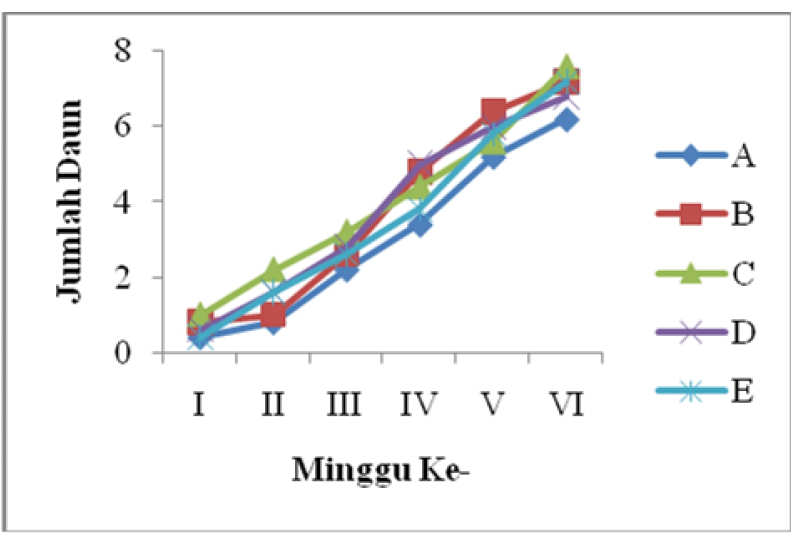

\section{Pembahasan}

Proses bertumbuh dan berkembang suatu tanaman mampu dicapai melalui pembelahan, pembesaran dan diferensiasi sel, dan melibatkan faktor genetik, fisiologi, ekologi, morfologi serta interaksi kompleksnya(Anggrainiet al., 2015). Pemberian pupuk merupakan salah satu upaya untuk meningkatkan proses bertumbuh dan berkembang suatu tanaman. Adapun respon dari setiap jenis tanaman berbeda-beda ketika diberi perlakuan pupuk.

Pemberian dosis pupuk bokashi super pada semua parameter pengamatan tidak memberikan hasil yang cukup berbeda antar perlakuan, hal ini diduga disebabkan karena pupuk bokashi merupakan pupuk organik yang bersifat slow release, artinya unsur hara dalam pupuk dilepaskan secara perlahan-lahan dan terus-menerus dalam jangka waktu tertentu, sehingga unsur hara tidak segera tersedia bagi tanaman (Musnawar, 2003). Diduga bokashi memerlukan waktu yang lama (slow release) untuk dapat diserap oleh tanaman.

Pertumbuhan buni tidak terlalu berbeda antar setiap perlakuan (baik yang tanpa diberi pupuk maupun yang diberi perlakuan pupuk). Sama halnya seperti penelitian Narendra (2012) dimana pemberian pupuk kandang pada Buni umur satu tahun tidak memberikan pengaruh yang nyata terhadap pertumbuhan diameter dan tinggi tanaman.

Sifat pupuk Bokashi yang slow release dan sifat tanaman Buni yang tidak terlalu responsif terhadap pemberian pupuk (Narendra, 2012) menjadi poin utama perbedaan pertumbuhan yang tidak terlalu signifikan antara tanaman yang tidak diberi pupuk dengan tanaman yang diberi perlakuan pupuk.

\section{Kesimpulan}

Perlakuan pemberian beberapa dosis pupuk Bokashi pada tanaman Buni umur satu tahun tidak memberikan perbedaan pertumbuhan yang cukup nyata dengan perlakuan tanpa diberi pupuk.Pertumbuhan tanaman buni yang konsisten meningkat baik dalam pertumbuhan diameter, tinggi maupun jumlah daun terdapat pada tanaman yang diberi perlakuan pupuk $200 \mathrm{~g} /$ polybag.

\section{Ucapan Terimakasih}

Penulis mengucapkan terimakasih kepada Kementerian Riset, Teknologi dan Pendidikan Tinggi Republik Indonesia atas Dana hibah yang diberikan untuk melakukan penelitian ini.

\section{Daftar Pustaka}

Anggraini, N, Faridah, E., dan Indrioko, S. 2016. Pengaruh Cekaman Kekeringan terhadap Perilaku Fisiologis dan Pertumbuhan Bibit Black Locus (Robinia pseudoacacia). Jurnal Ilmu Kehutanan 9 (1) : 41-56.

Gratimah, R.G. 2009. Analisis Kebutuhan Hutan Kota Sebagai Penyerap Gas CO2 Antropogenik Di Pusat Kota Medan. Tesis. PascaSarjana USU. Diakses 
http://repository.usu.ac.id/handle/1 23456789/5818

Higa, T. dan G.N. Widana. 1996. Tanya Jawab Technology "Effective Micro-organism 4". Hlm 3-10. Koperasi Karyawan Departemen Kehutanan, Jakarta.

Hamzah, F. 2007. Pengaruh Penggunaan Bokashi Kotoran Sapi Terhadap Pertumbuhan dan Produksi Tanaman Jagung.

Instalasi Penelitian dan Pengkajian Teknologi Pertanian (IP2TP). 2000. Pemanfaatan Limbah Pertanian sebagai Pupuk Organik. Jakarta.

Kassem, M.E.S., Hashim, A.N., dan Hassanein, H.M. 2013. Bioactivity of Antidesma bunius Leaves (Euphorbiaceae) and Their Major Phenolic Constituents. European Scientific Journal June 2013 edition 9 (18):217-228

Lim, T.K. 2012. Edible Medical and NonMedical Plants, Volume 4: Fruits. Springer. New York.

Musnawar, E.I. 2003. Pembuatan dan Aplikasi Pupuk OrganikPadat. Penebar Swadaya,Jakarta.

Narendra, B.H. 2012. Pengaruh Perbaikan Kondisi Tanah terhadap Pertumbuhan Kaliandra (Calliandra calothyrsus) dan Buni (Antidesma bunius) di Kawasan Konservasi Gunung Batur, Bali. Jurnal Penelitian Hutan dan Konservasi Alam 9(2) : 101-111

Ong, H.G., dan Kim, Y.D. 2017. The role of wild edible plants in household food security among transitioning hunter-gatherers: evidence from the Philippines. Food Sec. 9:11-24

Wulandari, D. 2011. Informasi Singkat Benih (Antidesma Bunius L.Spreng). Diakses dari: www.bpthsulawesi.net 